\title{
STUDY OF ONION PROCESSING WASTE POWDER FOR POTENTIAL USE IN FOOD SECTOR
}

\author{
T. Prokopova* , A. Slavov ${ }^{\mathrm{b}}$, N. Petkova ${ }^{\mathrm{b}}$, V. Yanakieva ${ }^{\mathrm{c}}$, B. Bozadzhiev ${ }^{\mathrm{d}}$ and D. Taneva \\ ${ }^{a}$ Department of Environmental Engineering, \\ ${ }^{\mathrm{b}}$ Department of Organic Chemistry, \\ ${ }^{\mathrm{c} D}$ Department of Microbiology, \\ ${ }^{\mathrm{d}}$ Department of Technology of Cereal, Bread and Confectionary Products, University of Food Technologies, 26 \\ Maritsa Blvd., 4000 Plovdiv. Bulgaria
}

(Received: 5 July 2017; accepted: 20 November 2017)

The development of food products that contain value-added dietary fibre beside different classes of phytochemicals is of great interest nowadays. The present research aimed to evaluate the powder obtained from onion processing waste (OPW) for its potential use as a value-added by-product in food sector. Data on chemical and microbiological characterization of onion processing waste powder (OPWP) were obtained. The dietary fibre content and antioxidant activity were also determined. The results showed that the OPWP was a low-calorie natural source of insoluble fibres $(60.52 \pm 0.13 \mathrm{~g} / 100 \mathrm{~g} \mathrm{dw})$, total phenols $(41.04 \pm 1.22 \mathrm{mg} \mathrm{GAE} / \mathrm{g} \mathrm{dw})$, and total flavonoids $(20.44 \pm 1.22 \mathrm{mg} \mathrm{QE} / \mathrm{g} \mathrm{dw})$. Moreover, the OPWP could be considered as an important source of total fructans $(9.04 \pm 0.28 \mathrm{~g} / 100 \mathrm{~g} \mathrm{dw})$, fructooligosaccharides $(2.76 \mathrm{~g} / 100 \mathrm{~g} \mathrm{dw})$, and inulin $(2.41 \pm 0.18 \mathrm{~g} / 100 \mathrm{~g} \mathrm{dw})$. In conclusion, this OPWP could be used as a value-added and healthy food ingredient.

Keywords: assessment, vegetable, by-product, value-added, healthy, ingredient

Currently, the global onion (Allium cepa L.) production is 82.9 million tons, making this vegetable the second most important horticultural crop worldwide after tomato. The EU-28 produced an estimated 6.4 million tons of onions in 2014, whereas the Bulgarian production counted around 13000 tons (ForTI \& HENRARD, 2016). Onion processing generates large amount of solid waste, hence it is necessary to find a way of utilising them. Onion processing waste (OPW) consists mainly of the top and bottom of onion bulbs and the two outer fleshy scales together with the brown skins. The mineral, dietary fibre, non-structural carbohydrate, alk(en)yl cysteine sulphoxide, and flavonoid contents and the antioxidant activity in different sections of OPW of two Spanish cultivars have been described (Benítez et al., 2011). Also, LY and co-workers (2005) found that the dry outer scales of onion contained large amounts of quercetin, quercetin glycoside, and their oxidative products, which were effective antioxidants against non-enzymatic lipid oxidation. Most studies have reported that different sections of the onion bulb may serve as promising sources of natural antioxidants for the development of nutraceuticals or value-added products (RoLDÁN et al., 2008; AlBISHI et al.,

\footnotetext{
* To whom correspondence should be addressed.

Phone: +359 32603 888; fax:+359 32644 102; e-mail: tsvetko_prokopov@abv.bg
}

This is an open-access article distributed under the terms of the Creative Commons Attribution-NonCommercial 4.0 International License (https://creativecommons.org/licenses/by-nc/4.0/), which permits unrestricted use, distribution, and reproduction in any medium for non-commercial purposes, provided the original author and source are credited, a link to the CC License is provided, and changes - if any - are indicated.

0139-3006 (C) 2018 The Author(s) 
2013). On the other side, BENíteZ and co-workers (2011) reported that onion composition was variable and depended on the cultivar, maturation stage, environment, storage time, and bulb section. Therefore, it is necessary to study the composition of each OPW to know its potential use for food purposes. Although several investigations had been done on different parts of onion bulb to gain knowledge of their characteristics, the information regarding evaluation of powder obtained from industrial OPW is scanty. Therefore, the chemical and microbiological characterization of the powder obtained from OPW was carried out in the present study. Also, the contents of dietary fibres, total phenols, flavonoids, soluble sugars, fructooligosaccharides, and total fructans in the onion processing waste powder (OPWP) together with its antioxidant activity were described in order to evaluate its potential use as a value-added functional food ingredient.

\section{Materials and methods}

\subsection{Sample preparation}

The material used in this study was obtained from a local Bulgarian canning plant (Bulcons Parvomay JSC, Bulgaria) after the processing (peeling) of brown-skin onion bulbs. The OPW consisted of the apical trimmings of the bulbs and the outer dry and semidry layers. The material was transferred to the laboratory immediately after processing, and was double washed and cut into small pieces. The pieces of OPW were dried in an oven dryer (RP1962, MK Optikoelektron, Bulgaria) at $70^{\circ} \mathrm{C}$ for $16 \mathrm{~h}$, and ground into fine powder using a domestic electric mill (MKM-6003, BOSCH, Germany). The sample was stored in air-tight glass containers at $4{ }^{\circ} \mathrm{C}$ until analysis.

\subsection{Proximate analysis}

The proximate constituents, including moisture, ash, crude protein, and crude lipids were determined on dried ground sample. Moisture content was determined by oven drying (RP1962, MK Optikoelektron, Bulgaria) of a test sample at $105^{\circ} \mathrm{C}$ to a constant weight, ash content by igniting a test sample in a muffle furnace (MLW LM212.11, VEB Elektro, Germany) at $550{ }^{\circ} \mathrm{C}$ until light grey ash results, crude protein content by the classical macroKjeldahl method, by multiplying the nitrogen content by a factor of 6.25 , and crude lipid content by petroleum ether extraction using a Soxhlet apparatus. Total carbohydrates were obtained by the differences (BOUBAKER et al., 2016): Total carbohydrates $(\mathrm{g})=100-(\mathrm{g}$ protein $+\mathrm{g}$ lipids $+\mathrm{g}$ ash $+\mathrm{g}$ fibre). The total, soluble, and insoluble dietary fibre (TDF, SDF, and IDF) contents of the powder were determined by the enzymatic-gravimetric method, using the Bioquant 1.12979.0001 total dietary fibre assay kit (Merck, Germany) and the instructions provided by the manufacturer.

\subsection{Phytochemicals extraction}

For the extraction of phytochemical compounds (carbohydrates, phenols, and flavonoids), dried ground sample $(1.5 \mathrm{~g})$ was extracted with $70 \%(\mathrm{v} / \mathrm{v})$ ethanol in a solid to liquid ratio of 1:20 (w/v). The extraction procedure was performed in an ultrasonic bath (VWR, Malaysia, $45 \mathrm{kHz}$ and $30 \mathrm{~W}$ ) for $15 \mathrm{~min}$ at $45^{\circ} \mathrm{C}$ as described by PetKova and co-workers (2014a). 


\subsection{Determination of total fructans content}

The total fructans content of the obtained extract was determined spectrophotometrically at a wavelength of $480 \mathrm{~nm}$ with a resorcinol-thiourea reagent, and the results were expressed as fructose equivalent on the dry weight $(\mathrm{dw})$ plant material according to PetKova and coworkers (2014a).

\subsection{HPLC-RID analysis of non-structural carbohydrates (NSC) and fructooligosaccharides (FOS)}

Extract from dried ground sample was evaporated to dry waste under vacuum. The waste was dissolved in $2 \mathrm{ml}$ of distilled $\mathrm{H}_{2} \mathrm{O}$ and filtered through a $0.45 \mu \mathrm{m}$ PTFE filter (Isolab, Germany), then a $20 \mu \mathrm{l}$ sample was injected. Chromatographic separations were performed on HPLC instrument Elite Chrome Hitachi, coupled with refractive index detector (RID) Chromaster 5450 and analytical column Shodex ${ }^{\circledR}$ Sugar SP0810 (300 mm $\times 8.0 \mathrm{~mm}$ i.d.) operating at $85{ }^{\circ} \mathrm{C}$, with distilled $\mathrm{H}_{2} \mathrm{O}$ as mobile phase with $1.0 \mathrm{ml} \mathrm{min}{ }^{-1}$ flow rate. Carbohydrate standards as glucose, fructose, sucrose, l-kestose, and nystose (Sigma-Aldrich) and inulin (Frutafit ${ }^{\mathbb{R}}$ TEX, the Netherlands) were used. Peaks were identified by retention times with above-mentioned standards. The analyte concentrations were calculated as peak areas with reference to the calibration curves, prepared at 5 concentration levels $(0.5,1,2.5$, 5 , and $10 \mathrm{mg} \mathrm{ml}^{-1}$ ). The results were calculated on the dry weight (dw) plant material (PetKova et al., 2014b).

\subsection{Determination of total phenols and total flavonoids content}

The total phenols content of the extract was determined with Folin-Ciocalteu reagent. Gallic acid was used as calibration standard, and the results were expressed as mg gallic acid equivalents (GAE) per g (dw) plant material (STINTZING et al., 2005). The total flavonoids were determined using an $\mathrm{Al}\left(\mathrm{NO}_{3}\right)_{3}$ reagent and measuring the absorbance at $415 \mathrm{~nm}$. The results were presented as mg quercetin equivalents $(\mathrm{QE})$ per $\mathrm{g}(\mathrm{dw})$ plant material (KIVRAK et al., 2009).

\subsection{HPLC analysis of flavonoids}

Extract from dried ground sample was evaporated to dry waste under vacuum. The waste was dissolved in $10 \mathrm{ml}$ of methanol and filtered through a $0.45 \mu \mathrm{m}$ PTFE filter (Isolab, Germany). The determination of individual flavonoids was performed using a Waters 1525 Binary Pump HPLC system (Waters, Milford, MA, USA), equipped with a Waters 2484 dual $\lambda$ Absorbance Detector and Supelco Discovery HS C18 column $(5 \mu \mathrm{m}, 25 \mathrm{~cm} \times 4.6 \mathrm{~mm})$, and controlled by the Breeze 3.30 software, according to the procedure described by MARCHEV and co-workers (2011). For the flavonoid separation, the mobile phase consisted of $2.0 \%(\mathrm{v} / \mathrm{v})$ acetic acid and methanol. Myricetin, kaempferol, quercetin, hesperetin, apigenin, and luteolin (Sigma) were used for calibration standard curves. The detection was carried out at $380 \mathrm{~nm}$. The results were calculated on the dry weight $(\mathrm{dw})$ plant material.

\subsection{Determination of antioxidant activity}

The antioxidant activity of obtained extract was evaluated by two methods: DPPH (1,1-diphenyl-2-picrylhydrazyl) radical based on mixed hydrogen atom transfer (HAT) and single electron transfer mechanism, and FRAP (ferric reducing antioxidant power) based 
only on the single electron transfer mechanism. The DPPH assay was performed as described by KIVRAK and co-workers (2009), and the FRAP assay was performed according to BENZIE and Strain (1996). The results were expressed as mM Trolox ${ }^{\circledR}$ equivalents (TE) per g dry weight $(\mathrm{dw})$ plant material.

\subsection{Microbiological examination}

The total mesophilic aerobic and facultative anaerobic bacteria, Escherichia coli, coagulasepositive Staphylococci, Salmonella spp., moulds and yeasts in dried ground sample were determined according to the official standards (EN ISO 4833-1, 2013; ISO 16649-2, 2014; EN ISO 6888-1, 2005; EN ISO 6579-1, 2017; EN ISO 21527-2, 2011, respectively).

\subsection{Statistical analysis}

All experiments were run in triplicate. The data were analysed and presented as mean values with standard deviation. Statistical techniques, incl. ANOVA and Duncan's Multiple Range Test, were applied to determine the significant differences at 95\% confidence $(\mathrm{P}<0.05)$ level.

\section{Results and discussion}

The chemical characteristics of the OPWP used in this study have been summarized in Table 1 .

Table 1. Chemical characteristics of the OPWP

\begin{tabular}{lcc}
\hline Parameter & & Value \\
\hline Moisture & $(\%)$ & $5.77 \pm 0.20$ \\
Crude protein & $(\mathrm{g} / 100 \mathrm{~g} \mathrm{dw})$ & $8.50 \pm 0.04$ \\
Crude lipids & $(\mathrm{g} / 100 \mathrm{~g} \mathrm{dw})$ & $1.34 \pm 0.01$ \\
Carbohydrates & $(\mathrm{g} / 100 \mathrm{~g} \mathrm{dw})$ & $14.55 \pm 0.47$ \\
Total ash & $(\mathrm{g} / 100 \mathrm{~g} \mathrm{dw})$ & $5.88 \pm 0.21$ \\
Total dietary fibres (TDF) & $(\mathrm{g} / 100 \mathrm{~g} \mathrm{dw})$ & $69.73 \pm 0.21$ \\
Soluble dietary fibres (SDF) & $(\mathrm{g} / 100 \mathrm{~g} \mathrm{dw})$ & $9.21 \pm 0.08$ \\
Insoluble dietary fibres (IDF) & $(\mathrm{g} / 100 \mathrm{~g} \mathrm{dw})$ & $60.52 \pm 0.13$ \\
Energy value & $(\mathrm{kJ} / 100 \mathrm{~g} \mathrm{dw})$ & $1019.72 \pm 5.06$ \\
\hline
\end{tabular}

Each value represents the mean value $\pm \mathrm{SD}$ of three independent replicates. *: Carbohydrates $(\%)$ were calculated by the difference $[100-\%$ of (protein + lipids + ash + total dietary fibres)].

Carbohydrates and dietary fibres predominated, whereas the lipid content was low $(1.34 \pm 0.01 \mathrm{~g} / 100 \mathrm{~g} \mathrm{dw})$, which made this waste material a low-calorie and healthy product. The TDF content was similar to that reported by ELLEUCH and co-workers (2011) for citrus peels. BENíTEZ and co-workers (2011) found that the dietary fibres of onion were cultivardependent and the OPW showed the highest TDF content with predominant IDF. Our results also indicated that IDF was the main fraction (86.79\%) of TDF.

The contents of soluble sugars, FOS, and total fructans in OPWP are presented in Table 2. 
Table 2. Content of soluble sugars, fructooligosaccharides, total fructans, total phenols, total flavonoids, and antioxidant activity of OPWP

\begin{tabular}{lcc}
\hline Parameter & & Value \\
\hline Sucrose & $(\mathrm{g} / 100 \mathrm{~g} \mathrm{dw})$ & $2.82 \pm 0.08$ \\
Glucose & $(\mathrm{g} / 100 \mathrm{~g} \mathrm{dw})$ & $2.43 \pm 0.12$ \\
Fructose & $(\mathrm{g} / 100 \mathrm{~g} \mathrm{dw})$ & $2.89 \pm 0.08$ \\
l-Kestose & $(\mathrm{g} / 100 \mathrm{~g} \mathrm{dw})$ & $1.81 \pm 0.28$ \\
Nystose & $(\mathrm{g} / 100 \mathrm{~g} \mathrm{dw})$ & $0.95 \pm 0.80$ \\
Inulin & $(\mathrm{g} / 100 \mathrm{~g} \mathrm{dw})$ & $2.41 \pm 0.18$ \\
Total fructans & $(\mathrm{g} / 100 \mathrm{~g} \mathrm{dw})$ & $9.04 \pm 0.28$ \\
Total phenols & $(\mathrm{mg} \mathrm{GAE} / \mathrm{g} \mathrm{dw})$ & $41.04 \pm 1.22$ \\
Total flavonoids & $(\mathrm{mg} \mathrm{QE} / \mathrm{g} \mathrm{dw})$ & $20.44 \pm 1.22$ \\
Antioxidant activity & & \\
DPPH assay & $(\mathrm{mM} \mathrm{TE} / \mathrm{g} \mathrm{dw})$ & $490.54 \pm 9.43$ \\
FRAP assay & $(\mathrm{mM} \mathrm{TE} / \mathrm{g} \mathrm{dw})$ & $114.05 \pm 8.04$ \\
\hline
\end{tabular}

Each value represents the mean value $\pm \mathrm{SD}$ of three independent replicates.

The NSC consist of fructans, sucrose, glucose, and fructose. Our results demonstrated that the main NSC fraction was due to fructans. The total fructans made up $50.8 \%$ of the NSC. Our findings were in agreement with the ranges reported by VAN LOO and co-workers (1995). BENíTEZ and co-workers (2011) reported different NSC distributions from the inner to the outer onion scales, because of its hydrolysis to fructose in the outer scale with lower dry matter content. Kestose, nystose, and fructofuranosyl nystose belong to the group of FOS (FRANK, 2002). In onion, FOS contribution to total fructans is more than $60 \%$ (VAN Loo et al., 1995). The sum of l-kestose and nystose in our study was $2.76 \mathrm{~g} / 100 \mathrm{~g} \mathrm{dw}$, which was about $50 \%$ of the value reported for the FOS content in dried powder from whole onion bulbs by Muir and co-workers (2007). Our study indicated that the main representative of FOS was l-kestose, which content was in accordance with the results reported for different sections of industrial OPW by BENíTEZ and co-workers (2011). We also found that the contribution of FOS and inulin to the total fructans was $30.5 \%$. The presence of FOS and inulin in the investigated OPWP showed that this material had possible technological functionality and a potential prebiotic effect (FrANK, 2002).

The total phenols and total flavonoids contents and the antioxidant activity of the investigated OPWP are presented in Table 2. Flavonoids were the major group of phenolic compounds, which was in agreement with the data for different parts of industrial OPW reported by BENíTEZ and co-workers (2011). The results obtained indicated that the investigated OPWP could be used as a rich source of flavonoids for improvement of antioxidant activity of food.

Furthermore, to obtain more detailed data about the flavonoid profile of the investigated sample, we analysed the contents of individual flavonoids by HPLC, and the results are presented in Figure 1.

The major flavonoid detected was quercetin $(356.77 \pm 1.23 \mathrm{mg} / 100 \mathrm{~g} \mathrm{dw})$. This fact is of great importance, since quercetin possesses several biological activities, such as antioxidative, anticancer, antimutagenic, anti-inflammatory, and antiviral activity (PRAKASH et al., 2007). 


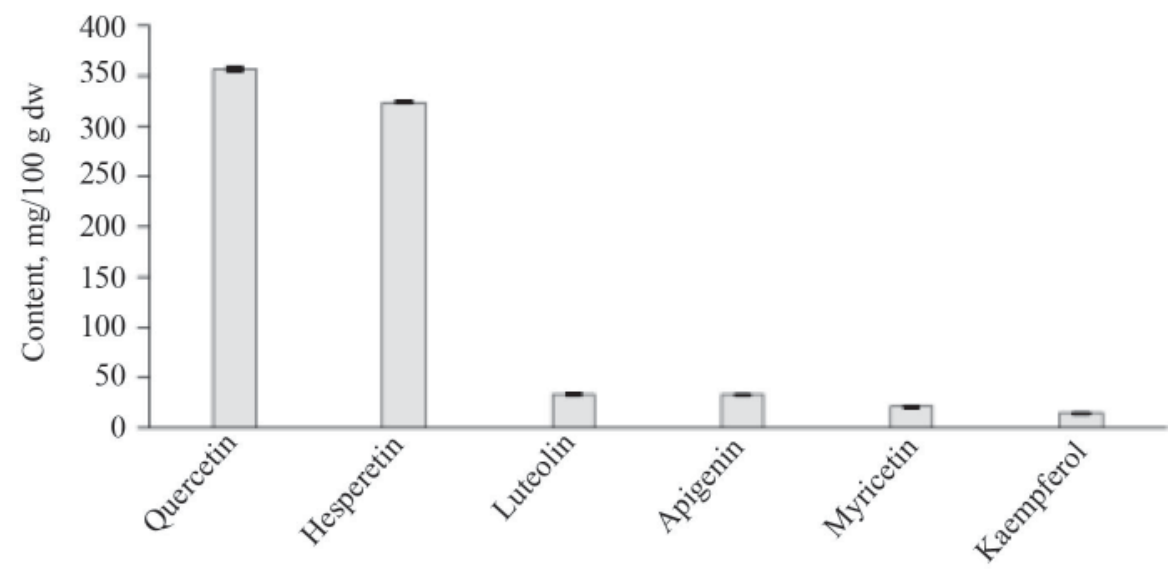

Fig. 1. Flavonoid composition of OPWP (Each value represents the mean value \pm SD of three independent replicates)

A lot of food wastes are used directly, after processing, or as extracts for formulation of foodstuffs with new and beneficial functional properties (РRокороv et al., 2015). For microbiological safety and product storage, it is important to have information about the possible presence of microorganisms. In this connection, the microbiological characteristics of the OPWP were investigated and the results are presented in Table 3.

Table 3. Microbiological characteristics of OPWP

\begin{tabular}{lccc}
\hline Parameter & Unit & Value & Limits* $^{*}$ \\
\hline $\begin{array}{l}\text { Total mesophilic aerobic and facultative } \\
\text { anaerobic bacteria }\end{array}$ & $\left(\mathrm{CFU} \mathrm{g}^{-1}\right)$ & $1.5 \times 10^{3}$ & $<1.0 \times 10^{6}$ \\
Escherichia coli & $\left(\mathrm{CFU} \mathrm{g}^{-1}\right)$ & $<10$ & $<10$ \\
Coagulase-positive Staphylococci & $\left(\mathrm{CFU} \mathrm{g}{ }^{-1}\right)$ & $<100$ & $<100$ \\
Salmonella spp. & $(\mathrm{CFU} / 25 \mathrm{~g})$ & 0 & 0 \\
Moulds and yeasts & $\left(\mathrm{CFU} \mathrm{g}^{-1}\right)$ & $1.0 \times 10^{3}$ & $1.0 \times 10^{4}$ \\
\hline
\end{tabular}

Each value represents the mean value $\pm \mathrm{SD}$ of three independent replicates. *: Bulgarian national microbiological limits for spices.

The presence of total mesophilic aerobic and facultative anaerobic bacteria, Escherichia coli, coagulase-positive Staphylococci, moulds and yeast is under the safety microbiological limits set for spices (ENIKOVA, 2006), Salmonella was not detected. The microbiological study indicated that the investigated material could be used as food component. 


\section{Conclusions}

The results showed that the OPWP could be potentially used as a value-added low-calorie functional food ingredient rich in dietary, mainly insoluble, fibre, total phenols, and total flavonoids, mainly quercetin, with a good antioxidant activity. Furthermore, this value-added waste material could be an interesting source of fructans, fructooligosaccharides, and inulin, with possible prebiotic effects. The recovery and utilization of OPW would also contribute to the solution of some environmental problems. Future investigations and assessment should be directed towards the optimisation of drying conditions and the incorporation of OPWP into different foods.

The authors thank the management of the Bulgarian local canning plant, Bulcons Parvomay JSC, Bulgaria for their help in providing industrial OPW and to Tsveta Horeva, Ph.D. for the language support.

This research received no specific grant from any funding agency in the public, commercial, or not-profit sectors.

\section{References}

Albishi, T., John, J., Al-Khalifa, A. \& Shahidi, F. (2013): Antioxidative phenolic constituents of skin of onion varieties and their activities. J. Funct. Foods, 5, 1191-1203.

Benítez, V., Mollá, E., Martin-Cabrejas, M., Aguilera, Y., López-Andréu, F., Cools, K., Terry, L. \& Esteban, R. (2011): Characterization of industrial onion wastes (Allium cepa L.): Dietary fibre and bioactive compounds. Plant Food. Hum. Nutr., 66, 48-57.

Benzie, I. \& Strain, J. (1996): The ferric reducing ability of plasma (FRAP) as a measure of antioxidant power: The FRAP assay. Anal. Biochem., 239(1), 70-76.

Boubaker, M., Damergi, C., Marzouk, C., Blecker, C. \& Bouzanita, N. (2016): Effect of artichoke (Cynara scolymus L.) by-product of the quality and total phenol content of bread. Mediterr. J. Chem., 5, 548-553.

Elleuch, M., Bedigian, D., Roiseux, O., Besbes, S., Blecker, C. \& Attia, H. (2011): Dietary fibre and fibre-rich by-products of food processing: characterisation, technological functionality and commercial application: A review. Food Chem., 124, 411-421.

EnIKova, R. (2006): Bulgarian national microbiological limits for foods. Advances in Bulgarian Science, 4, 34-31.

EN ISO 21527-2. (2011): Microbiology of food and animal feeding stuffs. Horizontal method for the determination of yeasts and moulds. Part 2: Colony count technique in products with water activity less than or equal to 0.95. CEN/TC 275, Brussels, Belgium.

EN ISO 4833-1. (2013): Microbiology of the food chain. Horizontal method for enumeration of microorganisms. Part 1: Colony count at $30^{\circ} \mathrm{C}$ by the pour plate technique. CEN/TC 275, Brussels, Belgium.

EN ISO 6579-1. (2017): Microbiology of the food chain. Horizontal method for the detection, enumeration and serotyping of Salmonella. Part 1: Detection of Salmonella spp. CEN/TC 275, Brussels, Belgium.

EN ISO 6888-1/A1. (2005): Microbiology of food and animal feeding stuffs. Horizontal method for the enumeration of coagulase-positive staphylococci (Staphylococcus aureus and other species). Part 1: Technique using Biard-Parker agar medium. Amendment 1: Inclusion of precision data. CEN/TC 275, Brussels, Belgium.

Forti, R. \& Henrard, M. (2016): Agriculture, forestry and fishery statistics. Eurostat Statistical Books, 2015 ed. Publication Office of the European Union, Luxembourg, 202 pages.

Frank, A. (2002): Technological functionality of inulin and oligofructoses. Brit. J. Nutr., 87, 287-291.

ISO 16649-2. (2014): Microbiology of food and animal feeding stuffs. Horizontal method for the enumeration of beta-glucuronidase-positive Escherichia coli. Part 2: Colony count technique at $44{ }^{\circ} \mathrm{C}$ using 5-bromo-4chloro-3-indolyl beta-D-glucuronide. International Organization for Standardization, Geneva, Switzerland.

Kivrak, I., Duru, M, Öztürk, M., Mercan, N., Harmandar, M. \& TopÇu, G. (2009): Antioxidant, anticholinesterase and antimicrobial constituents from the essential oil and ethanol extract of Salvia potentillifolia. Food Chem., $116,470-479$.

Ly, T., Hazama, C., Shimoyamada, M., Ando, H., Kato, K. \& Yamauchi, R. (2005): Antioxidative compounds from the outer scales of onion. J. Agr. Food Chem., 53(21), 8183-8189. 
Marchev, A., Georgiev, V., Ivanov, I., Badjakov, I. \& Pavlov, A. (2011): Two-phase temporary immersion system for Agrobacterium rhizogenes genetic transformation of sage (Salvia tomentosa Mill.). Biotechnol. Lett., 33, 1873-1878.

Muir, J., Shepherd, S., Rosella, O., Rose, R., Barrett, J. \& Gibson, P. (2007): Fructan and free fructose content of common Australian vegetables and fruit. J. Agr. Food Chem., 55, 6619-6627.

Petkova, N., Ivanov, I., Denev, P. \& Pavlov, A. (2014a): Bioactive substance and free radical scavenging activities of powder from Jerusalem artichoke (Helianthus tuberosus L.) tubers - a comparative study. Turk. J. Agr. Nat. Sci. (TURKJANS), 2, 1773-1778.

Petkova, N., Vrancheva, R., Denev, P., Ivanov, I. \& Pavlov, A. (2014b): HPLC-RID method for determination of inulin and fructooligosacharides. Acta Scientifica Naturalis (ASN), 1, 99-107.

Prakash, D., Singh, B. \& Upadhyay, G. (2007): Antioxidant and free radical scavenging activities of phenols from onion (Allium cepa). Food Chem., 102, 1389-1393.

Prokopov, T., Goranova, Z., Baeva, M., Slavov, A. \& Galanakis, C. (2015): Effects of powder from white cabbage outer leaves on sponge cake quality. Int. Agrophys., 29, 493-500.

RoldÁn, E., SÁnchez-Moreno, C., Ancos, B. \& CAno, M. (2008): Characterization of onion (Allium cepa L.) byproducts as food ingredients with antioxidant and antibrowning properties. Food Chem., 108, 907-916.

Stintzing, F., Nerbach, K., Mosshammer, M., Carle, R., Yi, W., Sellappan, S., Acoh, C., Bunch, R. \& Felker, P. (2005): Color, betalain pattern and antioxidant properties of cactus pear (Opuntia spp.) clones. J. Agr. Food Chem., 53, 442-451.

Van Loo, J., Coussement, P., De Leenheer, L., Hoebregs, H. \& Smits, G. (1995): On the presence of inulin and oligofructose as natural ingredients in the Western diet. Crit. Rev. Food Sci. Nutr., 35, 525-552. 